ABDIRA Volume 2 Nomor 1 Tahun 2022 Halaman 259-265

JURNAL PENGABDIAN MASYARAKAT

Research \& Learning in Faculty of Education

\title{
Pelatihan Membangun Jaringan RT/RW Net pada Karang Taruna Desa Kemelak Baturaja Timur
}

\author{
Sri Hartati ${ }^{1}$, Rusidi ${ }^{2}$ \\ Program Studi Manajemen Informatika, Universitas Mahakarya Asia \\ e-mail: hartatiakmi1984@gmail.com, rusidi081@gmail.com
}

\begin{abstract}
Abstrak
Pemutusan rantai penyebaran covid-19 adalah dengan melakukan social distancing. Social distancing menyebabkan banyak kegiatan yang beralih ke online. Kegiatan online telah meningkatkan kebutuhan internet masyarakat. Internet saat ini menjadi kebutuhan pokok bagi pelajar, mahasiswa, pedagang bahkan pegawai kantoran yang melaksanakan Work From Home (WFH). Karena itu dibutuhkan jaringan internet yang baik agar kegiatan online berjalan dengan lancar. Pemuda-pemudi Desa Kemelak Kecamatan Baturaja Timur yang tergabung dalam organisasi Karang Taruna berinisiatif utuk memasang jaringan internet sendiri. Namun keterbatasan pengetahuan dalam membangun jaringan internet ini maka diadakan pelatihan membangun jaringan internet yang diberi nama Jaringan RT/RW Net Desa Kemelak Kecamatan Baturaja Timur. Dengan adanya pelatihan ini diharapkan dapat memberikan ilmu yang cukup kepada pemuda-pemudi karang taruna Desa Kemelak Kecamatan Baturaja Timur dalam membangun jaringan internet. Dengan demikian Desa Kemelak Kecamatan Baturaja Timur akan dapat membangun jaringan internet sendiri yang dilaksanakan oleh Karang taruna.
\end{abstract}

Kata Kunci: Internet, karang taruna, pelatihan

\begin{abstract}
Breaking the chain of spread of covid-19 is by doing social distancing. Social distancing causes many activities to turn to online. Online activities have increased people's internet needs. The Internet is currently a staple for students, students, traders and even office employees who carry out Work From Home (WFH). Therefore, a good internet network is needed so that online activities run smoothly. The youths of Kemelak Village of East Baturaja District who are members of the Karang Taruna organization took the initiative to install their internet network. But the limitations of knowledge in building this internet network then held training to build an internet network called RT / RW Net Network Kemelak Village East Baturaja District. With this training is expected to provide enough knowledge to the youth of Karang taruna kemelak Village East Baturaja District in building an internet network. So, Kemelak Village of East Baturaja District will be able to build its internet network implemented by Karang taruna.
\end{abstract}

Keyword: Internet, Karang Taruna, training 


\section{PENDAHULUAN}

Sejak tahun 2019, kita dihadapkan pada kondisi yang tidak baik dikarenakan adanya pandemi covid-19. Dimasa pandemi Covid-19 memaksa perubahan perilaku manusia, terutama interaksi antara manusia untuk mengurangi dampak penyebaran virus ini. Sebagai upaya memutus rantai penyebaran covid-19 adalah dengan melakukan social distancin. Social distancing yang mengharuskan setiap manusia untuk mengatur jarak sosial berakibat banyak kegiatan yang sebelumnya dilakukan secara tatap muka harus beralih ke online.

Beberapa kegiatan yang dapat dilakukan secara online antara lain kegiatan belajar mengajar, kegiatan perdagangan hingga membuat konten untuk media sosial sebagai media mencari uang dimasa pandemi. Pada proses pembelajaran di sekolah maupun di perguruan tinggi. Pembelajaran tatap muka dalam kelas belum bisa dilakukan untuk kondisi saat ini sehingga digantikan dengan pembelajaran dalam jaringan atau Daring. Dibidang perdagangan sistem online saat ini sangat diminati, disamping penjual tidak harus memiliki toko, penjual juga bisa memasarkan produknya jauh lebih luas.

Penggunaan sistem online dalam setiap lini kehidupan ini tidak terlepas dari keberadaan jaringan internet yag memadai. Kebutuhan akan internet meningkat sangat signifikan selama pandemi ini berlagsung. Internet saat ini menjadi kebutuhan pokok bagi pelajar, mahasiswa, pedagang bahkan pegawai kantoran yang melaksanakan Work From Home (WFH). Oleh karena itu dibutuhkan jaringan internet yang mumpuni agar kegiatan online berjalan dengan lancar.

Desa Kemelak kecamatan Baturaja Timur adalah sebuh desa yang berada di Kabupaten Ogan Komering Ulu, Sumatera selatan. Dimasa pandemi ini masyarat desa yang terdiri dari pelajar, mahasiswa, pedagang dan pekerja kantoran sangat membutuhkan jaringan internet yang lancar. Saat ini jaringan internet yang dipakai masyarakat masih menggunakan paket data celuler dari handphone masing-masing. Hal ini menyebabkan kegiatan online tidak lancar dikarenakan tidak semua warga memiliki dana lebih untuk membeli paket data.

Melihat kondisi ini pemuda-pemudi Desa Kemelak kecamatan Baturaja Timur yang tergabung dalam organisasi Karang Taruna berinisiatif utuk memasang jaringan internet sendiri untuk masing-masing di tingkat rukun tetangga (RT) dan rukun warga (RW). Namun keterbatasan pengetahuan dalam membangun jaringan internet ini maka diadakan pelatihan membangun jaringan internet yang diberi nama Jaringan RT/RW Net Desa Kemelak kecamatan Baturaja Timur.

Tujuan kegiatan Pelatihan ini diharapkan dapat memberikan ilmu yang cukup kepada pemuda-pemudi karang taruna Desa Kemelak kecamatan Baturaja Timur dalam membangun jaringan internet. Dengan demikian Desa Kemelak 
kecamatan Baturaja Timur akan dapat membangun jaringan internet sendiri yang dilaksanakan oleh Karang taruna.

\section{METODE}

Kegiatan pelatihan membangun jaringan RT/RW Net pada karang taruna desa Kemelak Baturaja Timur Network Administrator ini dilakukan secara luring atau tatap muka dengan pemuda/pemudi karang taruna desa Kemelak Baturaja Timur dengan metode penyampaian materi, diskusi sekaligus melakukan praktikum langsung dengan membahas studi kasus yang diberikan. Kegiatan pengabdian masyarakat dilakukan dengan pendekatan dan penyampaian materi langsung kepada Karang Taruna. Pendekatan ini dilakukan dengan melibatkan pemuda-pemudi Karang Taruna yang menjadi sasaran dan subjek kegiatan, tidak hanya sekedar objek kegiatan. Dengan pendekatan ini dapat menumbuhkan kesadaran pemuda-pemudi Karang Taruna bahwa mereka masyarakat mempunyai masalah dalam menghadapi pembelajaran online. Pendekatan ini juga diperlukan untuk memberi jaminan kelancaran pelaksanaan kegiatan pelatihan. Secara garis besar kegiatan pelaksanaan dilakukan dalam 3 tahap yaitu Persiapan, Pelaksanaan. Dan Evaluasi dan Pelaporan.

\section{HASIL DAN PEMBAHASAN}

Waktu pelaksanaan sosialisasi dan workshop ini dilaksanakan selama 2 hari, yaitu tanggal 01 Desember 2021 dan 02 Desember 2021 dan bertempat di kampus Universitas Mahakarya Asia Baturaja dengan jadwal seperti berikut :

Tabel 1. Rincian Kegiatan

\begin{tabular}{|c|c|c|}
\hline Waktu & Materi & Penyaj \\
\hline $\begin{array}{l}01 \text { Desember } 2021 \\
08.30-12.00\end{array}$ & $\begin{array}{ll}\text { - } & \text { Konsep dasar jaringan } \\
\text { komputer } & \\
\text { - } & \text { Materi Pengenalan alat } \\
\text { jaringan }\end{array}$ & Sri Hartati \\
\hline $\begin{array}{l}01 \text { Desember } 2021 \\
13.30-16.00\end{array}$ & $\begin{array}{l}\text { - Budget untuk membangun } \\
\text { jaringan }\end{array}$ & Sri Hartati \\
\hline $\begin{array}{l}02 \text { Desember } 2021 \\
08.30-12.00\end{array}$ & - Subnetting pada IP address & Rusidi \\
\hline $\begin{array}{l}02 \text { Desember } 2021 \\
13.30-16.00\end{array}$ & - Konfigurasi topologi jaringan & Rusidi \\
\hline
\end{tabular}

Setelah dilakukan program kegiatan pengabdian ini dan dilakukan evaluasi terhadap proses dan hasil, maka diperoleh hasil sebagai berikut :

a. Pelatihan membangun jaringan RT/RW Net pada Desa Kemelak Baturaja Timur. Telah selesai dan lancar dilaksanakan dengan diikuti oleh 30 orang perwakilan karang taruna.

b. Materi Pelatihan membangun jaringan RT/RW Net pada Desa Kemelak Baturaja Timur ini yang terdiri dari :

1) Konsep dasar jaringan komputer dan jaringan RT/RW Net 
2) Materi Pengenalan jaringan, alat dan budget untuk membangun jaringan

3) Subnetting pada IP address

4) Konfigurasi topologi jaringan

c. Selanjutnya dilakukan diskusi dan tanya jawab jika ada pertanyaan dari para peserta setelah penyampaian materi

d. Antusias peserta sangat baik dan tidak sabar untuk segera praktik langsung

e. Akan diadakan pelatihan lanjutan utuk memaksimalkan ilmu yang diberikan

Hasil pelatihan menunjukaan semangat pemuda-pemudi karang taruna di dalam mengelola dan memajukan masyarakat di RT/RW nya dan pada penduduk desa pada umumnya.

Usaha internet Rt rw net ini memiliki pengaruh yang besar kepada masyarakat luas. Walaupun demikian proses pembangunan jaringan ini tidak dapat berjalan dengan lancar. Jika tanpa adanya dukungan dari masyarakat sekitar. Oleh karena itu, diperlukan tips berikut ini agar usaha pembangunan Rt/ rw net dapat berjalan dengan baik, yaitu:

a. Memperhitungkan Biaya Pembangunan dengan Cermat

Biaya pembangunan jaringan Rt rw net tidaklah sedikit. Oleh karena itu, diperlukan perhitungan yang matang dan mendetail di setiap peralatan dan pemasangan agar sesuai dengan budget yang dimiliki.

b. Tujuan Tidak Untuk Mencari Keuntungan Besar.

Tujuan dari Rt rw net ini adalah untuk memudahkan masyarakat dalam mengakses internet berkualitas kapanpun dibutuhkan. Oleh karena itu, biaya sewa yang ditetapkan juga jangan terlalu mahal dan memberatkan masyarakat. Keuntungan yang diharapkan juga harus wajar agar biaya operasional dapat tertutupi namun para pengguna tetap senang memakai jaringan Rt rw net ini.

c. Membangun Komunikasi yang Baik dengan Masyarakat

Bisnis ini membutuhkan dukungan besar dari masyarakat sekitar. Karenanya, diperlukan usaha untuk menjaga hubungan yang harmonis tersebut. Salah satu caranya adalah dengan ikut serta kegiatan lingkungan, berperan aktif dalam menyelesaikan permasalahan terkait jaringan Rt rw net dan lainnya. Hal ini penting karena dengan terjaganya hubungan tersebut maka bisnis internet ini akan terjaga untuk waktu yang lama.

d. Selalu belajar kepada yang lebih berpengalaman

Belajar kepada orang yang pernah membangun usaha Rt rw net tersebut sangatlah penting. Hal ini berguna untuk menghindari kesalahan yang mungkin terjadi ketika bisnis ini berjalan. Selain itu, pengusaha baru dapat meniru cara berbisnis internet ini baik dari sisi manajemen, 
pemilihan peralatan ataupun cara berkomunikasi dengan masyarakat setempat.

Tabel 2. Perkiraan Budget yang dikeluarkan

\begin{tabular}{|c|c|c|c|c|}
\hline NO & Keterangan & Satuan & Harga Satuan & Sub Total \\
\hline 1 & PC Server & 1 Unit & Rp 5.000.000,00 & Rp $5.000 .000,00$ \\
\hline 2 & PC Admin & 1 Unit & Rp $1.500 .000,00$ & $\begin{array}{ll}\mathrm{Rp} & 1.500 .000,00\end{array}$ \\
\hline 3 & Switch 8 Port & 5 Unit & Rp $300.000,00$ & Rp $1.500 .000,00$ \\
\hline 4 & $\begin{array}{l}\text { Mikrotik Router OS } \\
\text { dan Antenna }\end{array}$ & $1 \mathrm{Set}$ & Rp 2.000.000,00 & Rp $2.000 .000,00$ \\
\hline 5 & UPS min $1200 \mathrm{VA}$ & 1 Unit & Rp 1.000.000,00 & Rp $1.000 .000,00$ \\
\hline 6 & Kabel UTP & 1 Roll & Rp $1.000 .000,00$ & $\begin{array}{ll}\mathrm{Rp} & 2.000 .000,00\end{array}$ \\
\hline 7 & Meja/Rak server & 1 Unit & Rp 1.000.000,00 & Rp $1.000 .000,00$ \\
\hline 8 & Antena Omni & 2 Unit & Rp $\quad 500.000,00$ & $\begin{array}{ll}\mathrm{Rp} & 1.000 .000,00\end{array}$ \\
\hline \multicolumn{4}{|c|}{ TOTAL } & Rp. $15.000 .000,00$ \\
\hline
\end{tabular}

Berikut gambar saat pelatihan berlangsung:

RT RW Net adalah jaringan komputer yang tumbuh dari swadaya masyarakat. Sesuai dengan namanya, ini mencakup zona wilayah RT / RW. Dimana sistem operasionalnya, menggunakan kabel. Beberapa menggunakan Wireless $2.4 \mathrm{Ghz}$ serta hotspot sebagai media penghubung. Antar sumber internet dengan perangkat yang digunakan masyarakat.

\section{*Apa ity RT RW Net?}

Gambar 1 : Materi tentang RT/RW Net

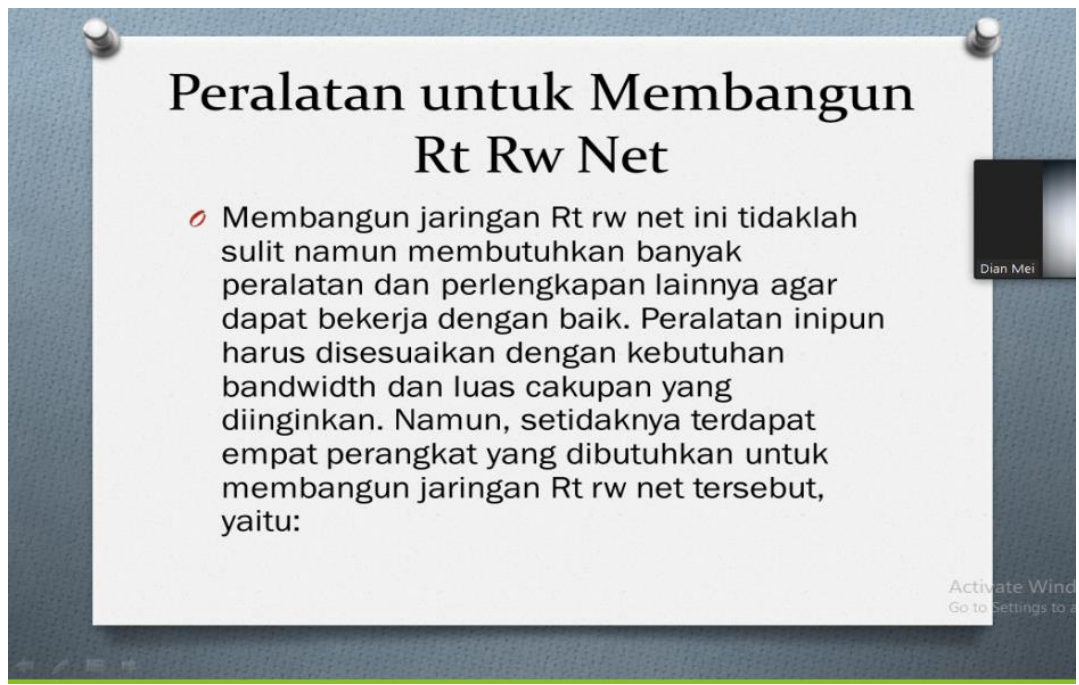

Gambar 2 : Materi tentang kebutuhan peralatan 


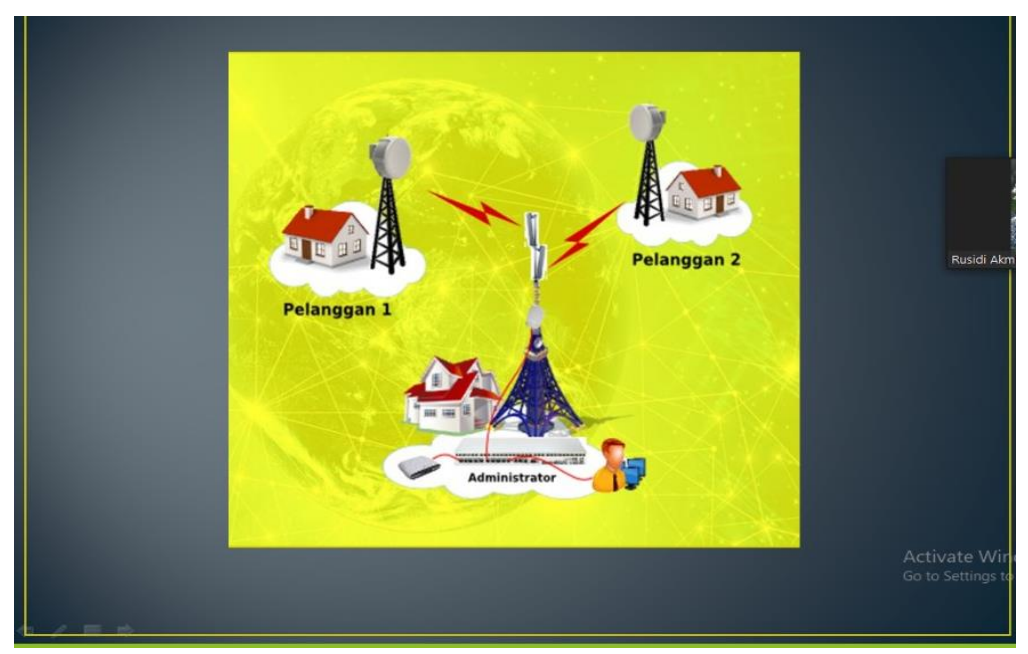

Gambar 3 : Materi tentang topologi

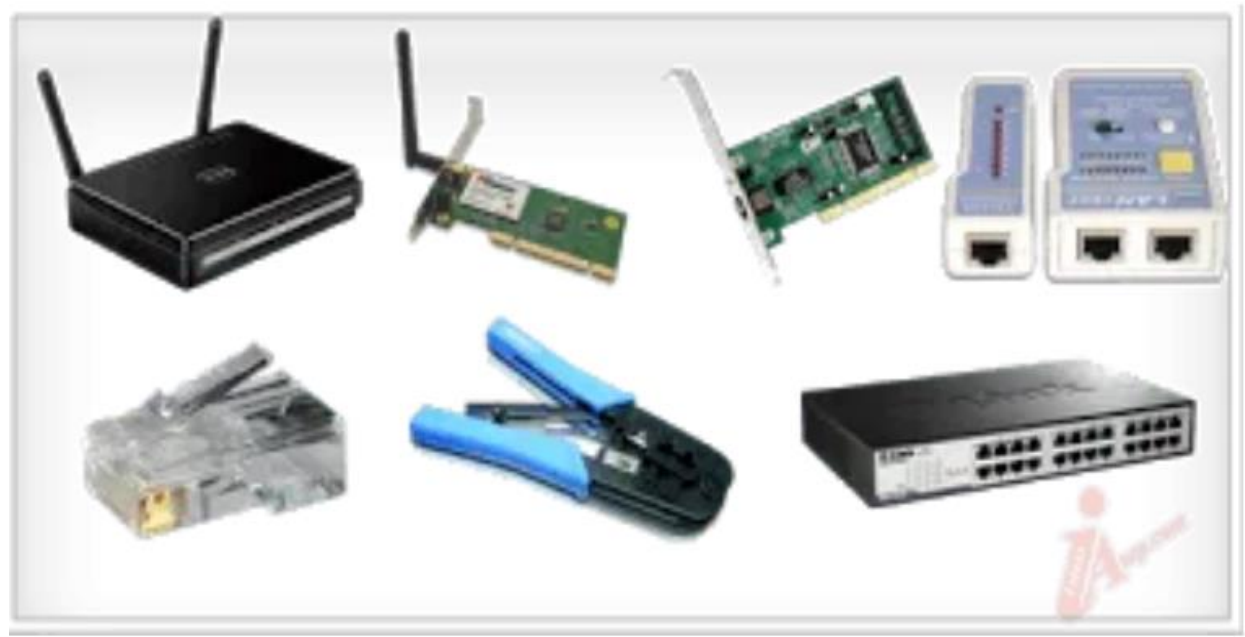

Gambar 4 : Alat untuk membangun jaringan

\section{SIMPULAN}

Dari kegiatan pelatihan yang dilakukan, dapat disimpulkan bahwa Peningkatan keahlian pemuda-pemudi karang taruna dalam usaha memajukan desa masing-masing adalah dengan beberapa cara antara lain pemberian motivasi dan mengadakan pelatihan-pelatihan sesuai dengan bidang dan kebutuhan. Dari pelaksanaan pengabdian masyarakat ini yang dilakukan bagi para anggota karang taruna desa Kemelak Baturaja Timur dengan tujuan meningkatkan pengetahuan dan keahlian para anggota karang taruna didalam bidang jaringan khususnya untuk membangun jaringan didapatkan kesimpulan bahwa dengan pelatihan ini dapat menambah pengetahuan para peserta mengenai jaringan khususnya dalam persiapan pembangunan jaringan RT/RW Net dan para peserta diharapkan dapat merancang jaringan mulai dari kebutuhan analisa kebutuhan alat dan harga, kebutuhan network dan vlan, ip address logical, serta topologi yang akan digunakan.

\section{DAFTAR PUSTAKA}

Efendi ilham : Pengertian dan macam-macam topologi jaringan. https://www.it-jurnal.com/pengertian-dan-macam-macam-topologi- 
jaringan-komputer/ diakses pada tanggal 29 Nov 2021

PSBB putuskan penularan covid-19 hotlines
https://www.kemkes.go.id/article/view/20051600002/psbb-putuskanpenularan-covid-19.html / diakses pada tanggal 29 Nov 2021

Pengertian Karang taruna. https://batukandik.desa.id/ diakses pada tanggal 30 Nov 2021

Madcoms (2003). Dasar teknis instalasi jaringan komputer. Madiun : Andi Yogyakarta

Cara membangun jaringan nT/RW net. http://webblogkkn.unsyiah.ac.id/mesjidgumpueng10/profil-gampong/ diakses pada tanggal 29 Nov 2021

Menghasilkan uang walau di rumah saja. https://indihome.co.id/blog/10-hobiyang-menghasilkan-uang-walau-hanya-dilakukan-di-rumah-saja / diakses pada tanggal 29 Nov 2021

Pengertian internet. https://id.wikipedia.org/wiki/Internet / diakses pada tanggal $30 \mathrm{Nov}$

Topologi jaringan komputer. https://kumparan.com/how-to-tekno/topologijaringan-komputer-mengenal-6-jenisnya-1vsJW8Wp8ZC / diakses pada tanggal $30 \mathrm{Nov}$ 